\title{
EVALUASI PEMANFAATAN MEDIA PEMBELAJARAN PADA MATA PELAJARAN PAI DI MTS DARUTTAQWA GRESIK
}

\author{
Nur Silva Nabila (F02318101) \\ Universitas Islam Negeri Sunan Ampel Surabaya, Indonesia \\ Email: halibanaflis@gmail.com
}

\begin{abstract}
Learning media evaluation aims to find out whether the effectiveness and efficiency of the media used in conveying learning content. Weaknesses and strengths of a media will be known by this program, whether the media needs to be improved or not. This article discusses the use of instructional media in PAI subjects at MTs Daruttaqwa with descriptive deductive and inductive analysis. Sources of data derived from literature, observation, and interviews were analyzed qualitatively. The purpose of this article is a) to find out the learning media used in MTS Daruttaqwa b) to find out the use of learning media in MTs Daruttaqwa c) to analyze the evaluation of learning media in MTs Daruttaqwa. The conclusions of this article are a) The media used in PAI learning at MTs Daruttaqwa in the form of technology-based media such as language labs, computer labs, projectors and manual-based media such as props for example paper that contains a collection of pieces of verses of the Koran in Qur'an Hadith and other subjects b) Media used in PAI learning in MTs Daruttaqwa in the form of technology-based media and manual-based media c) PAI learning media in MTs Daruttaqwa is only limited to teaching aids for teachers and not as something that needs and much needed in learning activities
\end{abstract}

Keywords: Evaluation, Utilization, Learning Media, PAI Subjects.

Abstrak: Evaluasi media pembelajaran bertujuan untuk mengetahui apakah efektifitas dan efesiensi media yang digunakan dalam menyampaikan isi pembelajaran. Kelemahan dan kekuatan dari sebuah media akan diketahui dengan program ini, apakah media tersebut perlu diperbaiki atau tidak.Artikel ini membahas pemanfaatan media pembelajaran pada mata pelajaran PAI di MTs Daruttaqwa dengan analisis deskriptif deduktif dan induktif. Sumber data berasal dari literatur, observasi, dan wawancara yang dianalisis secara kualitatif. Tujuan artikel ini ialah a) untuk mengetahui media pembelajaran yang digunakan di MTS Daruttaqwa b) untuk mengetahui pemanfaatan media pembelajaran di MTs Daruttaqwa c) untuk menganalisis evaluasi media pembelajaran di MTs Daruttaqwa. Adapun kesimpulan dari artikel ini ialah a) Media yang digunakan dalam pembelajaran PAI di MTs Daruttaqwa berupa media berbasis teknologi seperti lab bahasa, lab komputer, proyektor dan media berbasis manual seperti alat peraga contohnya kertas yang berisi kumpulan potongan ayat-ayat al-Qur'an dalam mata pelajaran Qur'an Hadits dan lainnya b) Media yang digunakan dalam pembelajaran PAI di MTs Daruttaqwa berupa media berbasis teknologi dan media berbasis manual c) media pembelajaran PAI di MTs Daruttaqwa hanya sebatas alat bantu mengajar bagi guru dan bukan sebagai suatu hal yang perlu dan sangat dibutuhkan dalam kegiatan pembelajaran

Kata Kunci: Evaluasi, Pemanfaatan, Media Pembelajaran, Mata Pelajaran PAI. 


\section{Pendahuluan}

Pendidikan merupakan hak yang layak didapatkan oleh semua manusia, di dalam suatu pendidikan terdapat proses pembelajaran. Proses pembelajaran merupakan suatu yang sangat kompleks, disebabkan dalam proses tersebut terdapat interaksi antara satu orang dengan yang lainnya serta terjadi komunikasi timbal-balik yang berlangsung dalam situasi edukatif untuk mencapai suatu tujuan pembelajaran. ${ }^{1}$ dalam interaksi tersebut melibatkan pendidik (guru) dan peserta didik (murid). Keduanya merupakan faktor integral dalam mempengaruhi berhasil atau tidaknya suatu pembelajaran.

Kemajuan zaman yang semakin pesat tentu pendidikan juga mengalami kemanjuan yang sangat pesat. Pendidik dituntut untuk kreatif dalam melaksanakan tugasnya. Salahsatunya ialah dalam hal menyampaikan materi yang disampaikan kepada peserta didik, guru dituntut sekreatif mungkin dalam menggunakan media pembelajaran agar peserta didik dapat memahami materi secara baik. Media pembelajaran menjadi salah satu saran yang dapat meningkatkan mutu pembelajaran. Pemanfaatan media pembelajaran dalam proses kegiatan belajar dapat memperbaiki belajar yang mengajar monoton. Adanya media pembelajaran akan menarik perhatian siswa sehingga dapat menumbuhkan motivasi belajar siswa, materi akan lebih mudah dipahami oleh siswa sebab bahan pembelajaran akan lebih jelas maknanya dan memungkin kan siswa menguasai tujuan pembelajaran lebih baik.

Media pembelajaran juga merupakan alat atau sesuatu yang bersifat mentransformasikan materi yang mana merupakan bagian yang pokok dari proses pembelajaran sebelum digunakan perlu di evaluasi terlebih dahulu, baik dari segi mutu teknisnya, segi edukatifnya, maupun segi isi materinya, sehingga media tersebut layak untuk digunakan sebagai media pendidikan. Untuk mengukur berhasilnya suatu media tersebut diperlukan adanya evaluasi. Evaluasi didefinisikan sebagai suatu komponen yang sistematis untuk menentukan berhasil atau tidaknya suatu pembelajaran. Melalui proses evaluasi pendidik akan mengetahui sejauh mana penyampaian materi pendidikan dan tujuan pendidikan tercapai atau tidak, sesuai standart yang di tentukan.

Evaluasi media di maksudkan untuk mengetahui apakah media yang digunakan dapat mencapai tujuan yang ditetapkan atau tidak. Hal ini penting untuk diperhatikan karena pada umumnya pendidik beranggapan bahwa sekali mereka menggunakan media dalam pembelajaran sudah pasti baiknya. Untuk itu perlu di buktikan kembali dengan cara menguji.

Pendidikan Agama Islam merupakan salah satu mata pelajaran dalam seluruh lembaga pendidikan di Indonesia khususnya Lembaga pendidikan Islam seperti Madrasah Aliyah, Madrasah Tsanawiyah dan lainnya. mata pelajaran PAI selama ini kurang menarik minat peserta didik disebabkan metode dalam penyampaian materi terkesan monoton dan konvensional, terbukti banyaknya kasus pendidik yang tidak memanfaatkan media sesuai dengan bahan yang di ajarkan. Akibatnya, banyak peserta didik yang kurang tertarik memahami pelajaran yang disampaikan dan bosan terhadap pelajarannya. Hal ini diidentifikasikan sebagai masalah kurangnya wawasan pendidik dalam pengaplikasian media dalam pembelajaran tersebut. Sebagai pelajaran yang harus disampaikan tentunya guru dapat menggunakan berbagai cara atau memanfaatkan media yang ada untuk menyampaikan pelajaran tersebut agar dapat diterima oleh siswa dengan baik.

Penggunaan media pembelajaran dalam pendidikan harus disesuaikan dengan materi ajar agar penggunaannya dapat proporsional hal tersebut bertujuan agat metode mengajar tidak monoton dan tidak membosankan dalam artian lebih bervariasi, tidak semata-mata komunikasi melalui penuturuan kata-kata oleh pendidik, sehingga peserta didik tidak bosan, peserta didik berperan dalam kelas seperti mengamati, melakukan, mencatat, bertanya,

\footnotetext{
${ }^{1}$ Nuryani Rustaman, Ilmu Dan Aplikasi Pendidikan (Bandung: Imperial Bakti Utama, 2001) 03.
} 
mendemonstrikan sesuatu dan diskusi dalam kelas, sebab selama ini hanya mendengarkan guru saja menyampaikan materi. Lembaga Madrasah Tsanawiyah di Daruttaqwa memanfaatkan beberapa media baik itu berbasis teknologi atau manual dalam menyampaikan materinya termasuk mata pelajaran PAI. Berdasarkan penjelasan diatas, penulis akan membahas tentang evaluasi pemanfaatan media pembelajaran PAI secara lebih dalam dan luas dalam lembaga MTS di Daruttaqwa.

\section{Metode Penulisan}

Penelitian ini bersifat kualitatif, yaitu prosedur penelitian yang menghasilkan data deskriptif berupa kata tertulis atau lisan dari orang dan perilaku yang dapat diamati ${ }^{2}$. Artikel ini merupakan penulisan dengan analisis deskriptif deduktif dan induktif menggunakan beberapa data hasil dari beberapa literatur, observasi dan wawancara. Pembahasan dalam artikel ini tentang bagaimana pemanfaatan dan evaluasi penggunaan media pembelajaran pada mata pelajaran PAI di MTs Daruttaqwa. Sejumlah fakta yang terkait dengan hal-hal tersebut kemudian dianalisis secara kualitatif untuk mendapatkan deskriptif komprehensif tentang pemilihan media pembalajaran dan pemanfaatannya. Selanjutnya, akan diidentifikasi beberapa kendala dalam penggunaan media pembelajaran, faktor yang mempengaruhi, serta solusinya. Pemanfaatan media pembelajaran pada bab ini di fokuskan untuk media pembelajaran yang di gunakan dalam mata pelajaran PAI.

\section{Kajian Teori}

\section{Konsep Evaluasi Media Pembelajaran}

Menurut KBBI (Kamus Besar Bahasa Indonesia) evaluasi artinya penilaian3. Menurut Normand E Grondlund, evaluasi adalah suatu proses yang terstruktur dan sistematis untuk menentukan atau membuat keputusan sampai sejauh mana tujuan pembelajaran telah dicapai oleh peserta didik ${ }^{4}$. Nurgiyantoro juga mendefinisikan bahwa evaluasi adalah untuk menilai sampai mana visi itu digapai, yang berarti istilah evaluasi ini mengandung arti suatu tindakan atau suatu proses yang terstruktur untuk menentukan nilai dari sesuatu. Selain itu evaluasi merupakan proses yang terjadi secara kontinu terkait tentang penafsiran informasi dalam menilai keputusan yang dibuat dalam merancang satu sistem pengajaran. Sedangkan media pembelajaran ialah sarana pendidikan yang di-gunakan sebagai alat atau sarana dalam kegiatan pembelajaran dengan tujuan meningkatkan efesiensi dalam mencapai tujuan pembelajaran ${ }^{5}$.

Kesimpulan dari pendapat para ahli yang telah disebutkan bahwa evaluasi media pembelajaran adalah suatu rangkaian proses guna mengukur apakah media yang dimanfaatkan dalam suatu kegiatan belajar mengajar telah memenuhi atau tidak dengan tujuan yang ditentukan. Pada umumnya evaluasi media pembelajaran adalah bertujuan untuk mengetahui apakah efektifitas dan efesiensi media yang digunakan dalam menyampaikan isi pembelajaran. Kelemahan dan kekuatan dari sebuah media akan diketahui dengan program ini, apakah media tersebut perlu diperbaiki atau tidak ${ }^{6}$. Hal itu akan memudahkan pendidik dalam mengembangkan sebuah media sebagai alat dalam proses pembelajaran. Proses

\footnotetext{
${ }^{2}$ Lexy J Moleong, Metodologi Penelitian Kualitatif (Bandung: Remaja Rosdakarya, 1992) 5.

3 "Arti Kata Evaluasi-Kamus Besar Bahasa Indonesia (KBBI) Online," accessed July 20, 2020, https://kbbi.web.id/evaluasi.

${ }^{4}$ Ngalim Purwanto, Prinsip-Prinsip Dan Teknik Evaluasi Pembelaajaran, XV. (Bandung: PT Remaja Rosdakarya, 2009) 03.

${ }^{5}$ Hujair AH Sanaky, Media Pembelajaran (Yogyakarta: Safiria Insania Press, 2009) 04.

${ }^{6}$ Asnawir and M Basyiruddin Usman, Media Pembelajaran (Jakarta: Ciputat Pers, 2002) 124.
} 
evaluasi merupakan bagian yang integral dan suatu proses intruksional. Idealnya keaktifan pelaksanaan proses intruksional diukur dari dua aspek:

a. Hasil nyata terkait hasil belajar siswa yang diketahui dari sistem intruksional

b. Bukti yang menunjukan kontribusi media pembelajaran terhadap keberhasilan dan kefektifan proses intruksional

Evaluasi tentang dua aspek di atas masih sangat sulit untuk dilakukan sebab media tidak berperan penuh dalam proses pengajaran, keaktifan guru dan siswa juga masih sangat dibutuhkan. Apabila media dirancang sebagai bagian integral dari proses belajar, jika diadakan evaluasi pengajaran maka sudah evalusia terhadap media yang digunakan sudah termasuk juga. Tujuan evaluasi media pembelajaran antara lain: ${ }^{7}$ a) mengetahui media yang digunakan efektif atau tidak b) mengetahui apakah media tersebut perlu perbaikan atau tidak c) menganalisis apakah media yang digunakan itu cost-effective atau tidak dilihat dari hasil belajar siswa d) penentuan media yang sesuai dengan materi pembelajaran e) apakah materi pembelajaran sudah tersampaikan dengan baik dengan media tersebut f) mengukur kapabilitas guru dalam menggunakan media tersebut g) memahami apakah media tersebut benar-benar berpengaruh terhadap hasil belajar siswa h) mengetahui sikap siswa terhadap media pembelajaran.

Evaluasi dapat dilakukan melalui beberapa cara, seperti diaskusi kelas dan kelompok interview perorangan, observasi mengenai sikap siswa, dan evaluasi media yang telah tersedia. Salah satu faktor kegagalam dalam mencapai tujuan belajar ialah kurang efektif nya media pembelajaran yang digunakan. Dengan melakukan dialog atau diskusi dengan siswa, maka sedikit banyak kita akan dapat informasi mengenai respon siswa terhadap metode pembelajaran yang digunakan, misalnya, siswa lebih suka belajar mandiri karena bisa fokus daripada harus belajar melalui media yang kita pilih. Atau, siswa menyukai jika menggunakan media-media tertentu, seperti siswa lebih menyukai penyajian materi melalui video, film atau lewat permainan. Dan tidak menyukai penyajian materi melalui buku teks atau media transpatansi. Hal tersebut bisa diketahui oleh pendidik dengan mengamati response siswa selama mengikuti pembelajaran apakah mereka antusiasme dalam belajar atau tidak. Harus dipahami bahwa evaluasi bukan final dari suatu pembelajaran yang telah kita susun, akan tetapi evaluasi merupakan awal dari siklus pembelajaran berikutnya, evaluasi juga dapat menentukan pembelajaran yang selanjutnya berhasil atau tidak. ${ }^{8}$

Ada beberapa kriteria dalam evaluasi media pembelajaran atau evaluasi tersebut dapat dikatakan efektif dan efesien apabila sebagai berikut: media yang digunakan sudah relevan dengan tujuan pembelajaran. Penggunaan waktu sesuai dengan yang di tentukan, misalnya dalam tingkat MTs tersedia waktu 2x40 menit, maka penggunaan media tidak boleh menghabiskan waktu tersebut dan hanya boleh di gunakan selama kegiatan inti pembelajaran. Kemudian, sesuai dengan tempat artinya penggunaan media proyektor harus berada di dalam ruangan dan tidaka boleh di luar, atau penggunaan media berbasis manual seperti boneka dan alat-alat memandikan jenazah harus sudah tersedia dan penggunaannya sebaiknya berada di ruangan yang sudah di tentukan. Media yang digunakan dapat menarik perhatian peserta didik serta guru harus sekreatif mungkin agar murid dapat tertarik untuk memahami materi melalui media tersebut. Murid harus memahami bagaimana maksud dan tujuan dari media pembelajaran. Kecakapan pendidik yang bersangkutan, sebab kecakapan atau kemampuan pendidik dalam menggunakan media juga mempengaruhi proses pembelajaran. Sangat penting dalam pemilihan media pembelajaran jad media yang di gunakan harus aktual dan mencakup isi materi yang seharusnya disampaikan. ${ }^{9}$

\footnotetext{
${ }^{7}$ Azhar Arsyad, Media Pengajaran (Jakarta: PT Raja Grafindo Persada, 2000) 173-174.

${ }^{8}$ Oemar Hamalik, Perencanaan Pengajaran (Jakarta: PT Bumi Askara, 2010).

${ }^{9}$ Azhar Arsyad, Media Pembelajaran (jakarta: Rajawali Press, 2001) 124.
} 


\section{Macam-Macam dan Prosedur Evaluasi Media Pembelajaran}

Jenis penilaian dalam meng-evaluasi media pembelajaran ada dua, yaitu: Evaluasi formatif: suatu proses yang dilakukan guna mengumpulkan data dan informasi terkait efisiensi dan efektifitas pemanfaatan media yang dalam usaha mencapai tujuan yang sudah di tentukan. Kemudian bukti tersebut digunakan untuk memperbaiki dan meningkatkan (to improve) media yang digunakan agar lebih efisien. Selain itu, terdapat evaluasi sumatif yang mana, media yang telah di sempurnakan, kemudian di telaah lagi apakah memadai atau tidak digunakan dalam keadaan tertentu serta biasanya dilakukan untuk memperoleh informasi dalam pembuatan keputusan tentang suatu produk atau media yang baru atau membuktikan (to prove) bahwa media yang dibuat benar-benar sempurna. Kegiatan evaluasi dalam media pembelajaran difokuskan kepada kegiatan evaluasi formatif. Ada tiga tahap pada evaluasi formatif. berikut rinciannya: ${ }^{10}$

a. Evaluasi satu lawan satu (one to one)

Evaluasi ini dilaksanakan dengan memilih dua siswa atau lebih yang dapat mewakili dari populasi target dari media yang dibuat. Hendaknya kedua siswa yang dipilih memiliki kemampuan yang berbeda. Misalnya, satunya di bawah rata-rata dan satunya diatas ratarata. Prosedur pelaksanaannya adalah sebagai berikut: 1) jelaskan kepada siswa jika kita sedang merancang suatu media baru dan ingin mengetahui reaksi mereka 2) menyampaikan kepada siswa jika nanti salah, bukanlah karena mereka akan tetapi media yang digunakan kurang sempurna. Jadi, perlu diperbaiki. 3) usahakan keadaan senyaman mungkin agar siswa dapat terbuka dalam mengutarakan anggapan terkait media tersebut 4) selanjutnya, beri pre-test untuk mengetahui pemahaman dan interpretaasi siswa terhadap materi yang dimediakan. 5) kemudian sajikan media dan catat dalam penyajian media dibutuhkan berapa lama waktu yang. Perlu dicatat pula respon peserta didik bagian mana yang sukar di pahami 6) berikan tes yang mengukur keberhasilan tersebut (post test). 7) analisis data-data dan informasi yang sudah di kumpulkan.

\section{b. Evaluasi Kelompok Kecil (small group evaluation)}

Evaluasi ini diujicobakan kepada sekitar 10-20 siswa yang mewakili populasi target, peserta didik tersebut hendaknya mencermin-kan karakteristik populasi. Upayakan sampel tersebut terdiri dari berbagai tingkat kemampuan yang berbeda-beda dan gender yang berbeda. Prosedurnya sebagai berikut: 1) jelaskan kepada siswa bahwa media tersebut pada tahap formatif dan membutuhkan umpan balik guna menyempurnakannya 2) berikan tes awal (pre-test) untuk mengukur kemampuan dan pemahaman siswa terkait materi yang disampaikan melalui media tersebut 3) tugas-kan kepada peserta didik sejenak agar mereka dapat mempelajari media yang akan disajikan 4) catat berapa waktu dan feedback baik langsung atau tidak selama penyajian media 5) berikan post test untuk mengetahui seberapa banyak tujuan telah di-gapai 6) bagikan angket atau kuesioner kepada siswa seperti: menarik tidaknya materi melalui media tersebut, apa sebabnya, pemahaman siswa terhadap pesan melalui media tersebut, konsistensi tujuan dan materi, dan cukup tidaknya latihan tersebut 7) lakukan analisis terhadap data-data dan bukti yang telah terkumpul. ${ }^{11}$

c. Evaluasi lapangan (field evaluation)

Merupakan tahan akhir dari evaluasi formatif. Evaluasi ini merupakan penyempurna dari evaluasi-evaluasi sebelumnya. Dalam melakukan evaluasi ini designer memerlukan 30 siswa dengan karakteristik, potensi, lingkungan, jenis kelamin, minat belajar yang

\footnotetext{
${ }^{10}$ Husniyatus Salamah Zainiyati, Pengembangan Media Pembelajaran Berbasis ICT (Jakarta: Kencana, 2017).

${ }^{11}$ Ibid 168-169
} 
berbeda-beda. Hal yang harus dihindari pada tiap-tiap evaluasi adalah Halo Effect. Halo Effect ini muncul apabila kita menguji cobakan media kepada siswa yang masih belum familiar dengan media tersebut. Jika seperti itu, maka informasi yang diperoleh banyak dipengaruhi oleh sifat kebaruan tersebut sehingga kurang dapat dipercaya.

Prosedur dalam melakukan evaluasi lapangan ini ialah: 1) pilih 30 siswa yang mewakili populasi 2) jelaskan kepada siswa maksud uji coba lapangan dan hasil akhir yang akan dicapai. Upayakan siswa rileks dan berani mengemukakan penilaian. Dan jangan sampai siswa beranggapan bahwa uji coba tersebut hanya menguji kemampuan mereka 3) berikan pre-test seperti evaluasi sebelumnya 4) sajikan media yang sesuai dengan rencana pembuat-nya 5) catat semua respons dari siswa selama sajian. Begitu pula waktu yang sudah ditentukan 6) berikan tugas terakhir untuk mengukur pencapaia hasil belajar siswa. Kemudian di bandingkan dengan tes awal untuk mengetahui efektivitas dan efisiensi media yang telah dibuat 7) memberi kuesioner guna melihat bagaimana response dan sikap peserta didik terhadap media yang di sajikan 8) analisis data yang sudah diperoleh seperti kemampuan awal, skor tes awal dan akhir, waktu yang dibutuhkan, perbaikan bagian yang belum sempurna dan sebagainya.

\section{Hasil dan Pembahasan}

\section{Media Pembelajaran Dalam Mata Pelajaran PAI di Daruttaqwa Gresik}

Kegiatan pembelajaran PAI cenderung membosankan dan metode yang digunakan kurang bervariasi, sehingga menyebabkan PAI kurang diminati oleh peserta didik. Oleh karena itu, perlu adanya media pembelajaran yang dapat meningkatkan minat belajar peserta didik dan menjadi alat pendukung agar materi tersampaikan dengan baik. Pendidik pun dalam proses pembelajaran diharapkan mampu kreatif dalam membuat media pembelajaran dan menggunakannya dengan lebih baik. Media pembelajaran merupakan alat atau sarana yang digunakan dalam proses dan tujuan pembelajaran. Pada hakikatnya proses pembelajaran juga merupakan komunikasi, maka media pembelajaran bisa dipahami sebagai media komunikasi yang digunakan dalam proses komunikasi tersebut, media pembelajaran memiliki peranan penting sebagai sarana untuk menyalurkan pesan pembelajaran.

Dalam proses pembelajaran guru harus kreatif untuk memilih media yang akan di sajikan kepada murid guna memudahkan penyampaian materi agar mudah di-pahami. Jika media yang digunakan sesuai dengan kebutuhan peserta didik dan sesuai dengan materi pembelajaran maka akan meminimalisir terjadinya hambatan atau resiko selama pemelajaran. Resiko yang terjadi dapat berupa kurang tersampaikan-nya materi pembelajaran, kekacauan dalam memahami materi, peserta didik tidak fokus dalam mengikuti proses pembelajaran bisa jadi sebab kesehatan kurang baik, atau suasana pembelajaran yang membosankan, kurang aktifnya siswa, atau keadaan yang kurang nyaman seperti kelas kotor, tempat duduk yang tidak sesuai, ruang yang pengap ataupun media yang digunakan kurang memadai ${ }^{12}$.

Media yang digunakan dalam pembelajaran PAI di MTs Daruttaqwa berupa media berbasis teknologi dan media berbasis manual. Media berbasis teknologi seperti lab bahasa, lab komputer, proyektor yang menampilkan jenis media visual dibantu dengan media audio. Media pembelajaran berbasis manual seperti alat peraga contohnya kertas yang berisi kumpulan potongan ayat-ayat al-Qur'an dalam mata pelajaran Qur'an Hadits, boneka sekaligus seperangkat alat perawatan jenazah untuk mata pelajaran Fikih, gambar atau poster terkait materi seputar ibadah dalam mata pelajaran fikih.

\footnotetext{
${ }^{12}$ Husniyatus Salamah Zainiyati, Media Pembelajaran PAI: Teori Dan Aplikasinya (IAIN Sunan Ampel Press, 2013), accessed November 25, 2019, http://digilib.uinsby.ac.id/20148/.
} 
Media-media tersebut dipilih dalam pembelajaran PAI karena sudah tersedia, dan cost effective atau tidak membutuhkan banyak biaya, serta mudah dioperasikan oleh semua pendidik dan aman untuk digunakan. Selain itu, media-media tersebut juga sesuai dengan materi pembelajaran dan kebutuhan peserta didik.

\section{Pemanfaatan Media Pembelajaran dalam Mata Pelajaran PAI di MTS Daruttaqwa Gresik}

Menurut Hamalik, Pemanfaatan media pembelajaran dalam proses belajar mengajar dapat membangkitkan keinginan dan minat yang baru, membangkitkan motivasi dan rangsangan kegiatan belajar, dan membawa pengaruh-pengaruh psikologis terhadap siswa ${ }^{13}$. Penggunaan media pembelajaran pada mata pelajaran PAI di MTs Daruttaqwa masih terbilang sangat minim meskipun materi PAI telah dibagi menjadi mata pelajaran Aqidah Akhlak, Qur'an Hadist, Fiqih, dan SKI. Ada beberapa faktor yang menyebabkan hal tersebut terjadi seperti adanya beberapa guru yang masih banyak menggunakan metode konvensional seperti ceramah, kurangnya pengetahuan guru terkait media pembelajaran, dan terbatasnya media pembelajaran PAI yang disediakan.

Dalam prinsip penggunaan media pembelajaran, keterampilan guru dalam menggunakan media sangatlah penting, apapun jenis media yang diperlukan, semuanya tergantung apakah guru dapat menggunakannya dengan baik atau tidak dalam proses pembelajaran. Solusi yang ditawarkan dalam meningkatkan kemampuan guru dalam menggunakan media pembelajaran adalah diadakannya pelatihan mandiri tentang bagaimana cara menciptakan, menggunakan dan mengembangkan media pembelajaran yang tepat dan sesuai dengan kebutuhan peserta didik, menyediakan fasilitas-fasilitas belajar berupa media yang berkualitas, dan kemudian membuat kebijakan yang menganjurkan penggunaan media dalam setiap pembelajaran.

Menurut beberapa narasumber yang menjadi guru PAI di MTs Daruttaqwa ${ }^{14}$ pemilihan dan penggunaan media di MTs Daruttaqwa terkadang mengalami beberapa kendala. Dalam penggunaan Lab komputer guru-guru PAI masih membutuhkan tenaga ahli yang lebih mengerti tentang penggunaan lab komputer, begitu juga dengan lab bahasa yang mana terbatasnya jumlah komputer yang sedikit dibandingkan dengan jumlah siswa dalam tiap kelas. Selain itu, jumlah proyektor yang disediakan juga sangat terbatas, lebih sedikit di bandingkan dengan rombongan belajar yang ada. Proyektor hanya disediakan untuk kelas unggulan, sedangkan untuk kelas-kelas reguler hanya disediakan dua proyektor yang ada di kantor.

Kesulitan dan kendala yang di alami dalam penggunaan media manual ialah terbatasnya alat yang disediakan dan hanya dapat digunakan dalam materi pelajaran tertentu saja, seperti kertas peraga yang bertuliskan potongan ayat al-Qur'an hanya dapat digunakan untuk materi tajwid dalam mata pelajaran qur'an hadist, sedangkan boneka dan seperangkat alat perawatan jenazah hanya dapat digunakan saat pelajaran fiqih membahas materi perawatan jenazah saja. Serta terdapat kendala dalam mutu teknis media yang digunakan. Seringnya media tersebut digunakan sehingga membutuhkan biaya untuk perawatan agar media tersebut tetap bisa di gunakan.

\footnotetext{
${ }^{13}$ Arsyad, Media Pembelajaran 15.

${ }^{14}$ Hasil wawancara bersama ibu Siti Maysaroh (Guru PAI di MTs Daruttaqwa) pada tanggal 20 November 2019 di Kantor MTs Daruttaqwa
} 


\section{Evaluasi Pemanfaatan Media Pembelajaran PAI di MTS Daruttaqwa Gresik}

Evaluasi media pembelajaran adalah suatu rangkaian proses guna mengukur apakah media yang dimanfaat-kan dalam suatu kegiatan belajar mengajar telah memenuhi atau tidak dengan tujuan yang ditentukan. Pada umumnya evaluasi media pembelajaran adalah bertujuan untuk mengetahui apakah efektifitas dan efesiensi media yang digunakan dalam menyampaikan isi pembelajaran. Tujuan evaluasi media pembelajaran yang di sebutkan dalam buku pedoman Evaluasi Media Pendidikan dari Direktorat Jenderal Pendidikan Dasar dan Menengah tahun 1988-1989, yaitu: ${ }^{15}$

1. Memberikan pedoman kepada instansi pemerintah dalam mengadakan media pendidikan yang bermutu

2. Memberikan pedoman kepada guru dalam membuat media pendidikan yang bermutu

3. Memberikan pedoman kepada produsen dalam memproduksi media pendidikan yang bermutu

4. Melindungi sekolah dari penggunaan media pendidikan yang tidak dapat dipertanggungjawabkan dari segi teknis kependidikan.

Menurut data yang diperoleh dari wawancara dengan salah satu guru PAI di MTs Daruttaqwa, kegiatan evaluasi media pembelajaran pada mata pelajaran PAI di Mts Daruttaqwa hanya sebatas memperhatikan sikap dan respon peserta didik, hal itu bertujuan untuk mengetahui apakah media yang digunakan mampu menarik minat peserta didik atau tidak. Guru-guru PAI belum pernah membuat Draf pemilihan, penggunaan, dan evaluasi media pembelajaran. Sehingga kegiatan evaluasi media pembelajaran PAI belum tersistem dan terprogram dengan baik.

Setelah melakukan pengamatan dan observasi, kegiatan evaluasi media pembelajaran PAI di MTs Daruttaqwa Gresik hanya sebatas memperhatikan bagaimana sikap dan respon yang diberikan peserta didik selama penggunaan media tersebut berlangsung untuk mengetahui apakah media yang digunakan mampu menarik perhatian peserta didik atau tidak. Hal tersebut menyebabkan tidak adanya pengembangan dalam penggunaan media pembelajaran sehingga di khawatirkan kualitas pembelajaran PAI terbilang rendah. Oleh karena itu, Dalam mengevaluasi media pembelajaran, sebenarnya tidak hanya memperhatikan bagaimana sikap dan respon yang diberikan tetapi juga seharusnya mengikuti prosedur mengevaluasi media pembelajaran dengan menggunakan tiga atahapan seperti: evaluasi one to one, evaluasi small grup atau field evaluation. Setelah itu, beberapa pertanyaan seputar materi yang telah disampaikan melalui media tersebut juga perlu disampaikan untuk mengetahui apakah terdapat perbedaan sikap dan kondisi peserta didik selama penggunaan media pembelajaran berlangsung, apakah media pembelajaran yang digunakan dapat membantu peserta didik dalam memahami materi yang disajikan atau bahkan malah membuat peserta didik semakin bingung dan mempersulit dalam memahami materi pembelajaran.

Sebaiknya, setiap pendidik membuat draf perencanaan, penggunaan dan evaluasi media pembelajaran agar kegiatan evaluasi yang di lakukan dapat tersistem dan terprogram dengan baik. Selain itu, data yang diperoleh dapat dijadikan arsip untuk mengevaluasi media-media yang akan digunakan nantinya. Berikut ini disajikan contoh salah satu model draft untuk mereview dan mengevaluasi program dan mediaa pembelajaran dengan format yang sering digunakan oleh para guru di kelas:

${ }^{15}$ Arsyad, Media Pembelajaran. 


\section{Evaluasi Media Gambar Diam}

\begin{tabular}{|l|l|l|l|l|}
\hline \multirow{2}{*}{ NO } & \multicolumn{1}{|c|}{ KRITERIA } & \multicolumn{2}{c|}{ RATING } \\
\cline { 3 - 5 } & Relevan dengan sasaran belajar & Tinggi & Sedang & Rendah \\
\hline 2 & $\begin{array}{l}\text { Kesedarhanaan (Rapi, teratur, tidak tercampur } \\
\text { dengan bahan yang tidak relevan, objek yang tidak } \\
\text { perlu atau latar belakang yang mengganggu) }\end{array}$ & & & \\
\hline 3 & $\begin{array}{l}\text { Tidak ketinggalan zaman ( mode yang kuno dapat } \\
\text { mengundang tawa dan menyebabkan siswa } \\
\text { kehilangan maksud pesan gambar) }\end{array}$ & & & \\
\hline 4 & $\begin{array}{l}\text { Kualitas atau teknis (kontras yang bagus, memiliki } \\
\text { keterbacaan visual yang baik, warna alamiah dan } \\
\text { realistik) }\end{array}$ & & & \\
\hline 5 & $\begin{array}{l}\text { Ukuran (tepat, fleksibel, dapat digunakan untuk } \\
\text { kelompok besar dan juga untuk kelompok kecil) }\end{array}$ & & & \\
\hline
\end{tabular}

Beberapa hal di atas perlu dilakukan sebagai langkah kecil evaluasi formatif untuk mengetahui tingkat efisiensi penggunaan media pembelajaran. Selain evaluasi formatif, evaluasi sumatif juga perlu dilakukan untuk mengetahui hasil pembelajaran dan tingkat kemampuan siswa dalam memahami dan menerapkan materi yang telah disampaikan. Kedua evaluasi tersebut sangat penting dilakukan sebagai alat ukur yang menentukan apakah media pembelajaran yang telah dipilih layak digunakan lagi atau perlu beberapa perbaikan dan pengembangan atau bahkan sama sekali tidak layak digunakan lagi.

Di lain sisi, pemilihan media pembelajaran PAI di MTs Daruttaqwa dapat dibilang cukup baik karena telah memenuhi beberapa kriteria pemilihan media yang telah ditetapkan oleh para ahli. Media-media pembelajaran tersebut di atas mudah didapatkan karena memang sudah tersedia di MTs Daruttaqwa. Serta biaya yang diperlukan juga tidak banyak misalnya pemilihan media berupa proyektor dan gambar. Media yang digunakan sesuai dengan kebutuhan siswa dan harus diketahui apakah sudah sesuai dengan taraf berfikir siswa atau belum, sehingga makna yang terkandung di dalam-nya dapat mudah dipahami siswa. Siswa juga lebih antusias memahami materi yang disajikan melalui media daripada hanya mendengarkan penjelasan guru yang menjadikan situasi dalam kelas terasa membosankan. 


\section{Kesimpulan}

Evaluasi media pembelajaran adalah bertujuan untuk mengetahui apakah efektifitas dan efesiensi media yang digunakan dalam menyampaikan isi pembelajaran. Kelemahan dan kekuatan dari sebuah media akan diketahui dengan program ini, apakah media tersebut perlu diperbaiki atau tidak. Menurut hasil penelitian diatas, demikian yang dapat penulis simpulkan bahwa: Pertama, Media yang digunakan dalam pembelajaran PAI di MTs Daruttaqwa berupa media berbasis teknologi dan media berbasis manual. Media berbasis teknologi seperti lab bahasa, lab komputer, proyektor yang menampilkan jenis media visual dibantu dengan media audio. Media pembelajaran berbasis manual seperti alat peraga contohnya kertas yang berisi kumpulan potongan ayat-ayat al-Qur'an dalam mata pelajaran Qur'an Hadits dan lainnya. Kedua, Media yang digunakan dalam pembelajaran PAI di MTs Daruttaqwa berupa media berbasis teknologi seperti audio, proyektor, video tutorial dan media berbasis manual seperti poster, gambar, atau alat peraga dan alat-alat kebutuhan materi lainnya. Ketiga, Kegiatan evaluasi media pembelajaran pada mata pelajaran PAI di Mts Daruttaqwa hanya sebatas memperhatikan sikap dan respon peserta didik, hal itu bertujuan untuk mengetahui apakah media yang digunakan mampu menarik minat peserta didik atau tidak. Guru-guru PAI belum pernah membuat Draf pemilihan, penggunaan, dan evaluasi media pembelajaran. Sehingga kegiatan evaluasi media pembelajaran PAI belum tersistem dan terprogram dengan baik.

\section{Saran}

Materi diatas bagi penulis merupakan wujud konstitensi dalam menambah dan mengembangkan khazanah pengetahuan dan keilmuan khususnya tentang evaluasi pemanfaatan media pembelajarn dalam PAI, dan diharapkan :

a. Bagi pembaca dapat menjadi rujukan maupun sumber pengetahuan dan solusi tentang pemanfaatan media pembelajaran dan evaluasinya, khususnya dalam mata pelajaran PAI

b. Bagi guru, dapat memahami materi ini dengan baik, sehingga dapat menambah wawasan untuk mengevaluasi media pembelajaran agar layak dan dapat di gunakan dengan baik, khususnya dalam pembelajaran PAI. 


\section{Daftar Pustaka}

Arsyad, Azhar. Media Pembelajaran. jakarta: Rajawali Press, 2001.

-——. Media Pengajaran. Jakarta: PT Raja Grafindo Persada, 2000.

Asnawir, and M Basyiruddin Usman. Media Pembelajaran. Jakarta: Ciputat Pers, 2002.

Hamalik, Oemar. Perencanaan Pengajaran. Jakarta: PT Bumi Askara, 2010.

J Moleong, Lexy. Metodologi Penelitian Kualitatif. Bandung: Remaja Rosdakarya, 1992.

Purwanto, Ngalim. Prinsip-Prinsip Dan Teknik Evaluasi Pembelaajaran. XV. Bandung: PT Remaja Rosdakarya, 2009.

Rustaman, Nuryani. Ilmu Dan Aplikasi Pendidikan. Bandung: Imperial Bakti Utama, 2001.

Sanaky, Hujair AH. Media Pebelajaran. Yogyakarta: Safiria Insania Press, 2009.

Zainiyati, Husniyatus Salamah. Media Pembelajaran PAI: Teori Dan Aplikasinya. IAIN Sunan Ampel Press, 2013. Accessed November 25, 2019. http://digilib.uinsby.ac.id/20148/.

_-_ Pengembangan Media Pembelajaran Berbasis ICT. Jakarta: Kencana, 2017.

“Arti Kata Evaluasi - Kamus Besar Bahasa Indonesia (KBBI) Online.” Accessed July 20, 2020. https://kbbi.web.id/evaluasi. 